\title{
FENOMENA PORNOTEKS DI KOLOM KOMENTAR SELEBRITI INSTAGRAM @SARAHVILO.ID SEBAGAI MASALAH SOSIAL PADA MEDIA BARU
}

\author{
Shinta Hartini Putri ${ }^{1)}$, Leoni Oktavia Maharani ${ }^{2)}$ \\ ${ }^{1,2}$ Fakultas Komunikasi dan Desain, Universitas Informatika dan Bisnis Indonesia \\ Email : $\underline{\text { shintahartiniputri@unibi.ac.id }}{ }^{1}, \underline{\text { Leonioktavia1610@gmail.com² }}^{2}$
}

\begin{abstract}
Abstrak
Media sosial khususnya Instagram, telah menjadi salah satu sarana untuk mengekplorisasi dan mengekpresikan diri. Instagram menyajikan fitur-fitur interaktif dalam memudahkan penggunanya, namun tidak semua pengguna Instagram bijak dan menaati etika dalam berkomunikasi di sosial media. Hal tersebut terjadi pada akun Selebgram Sarah Viloid yang memiliki jutaan pengikut, setelah menanjaknya pengikut Sarah, komentar-komentar berunsur pornoteks mulai bermunculan dan semakin sering ditemui di hampir setiap unggahan foto Sarah. Tentunya komentar tersebut akan menciptakan rasa tidak nyaman, baik bagi Sarah sebagai pemilik akun, maupun bagi pengguna Instagram lain yang membaca komentar tak senonoh tersebut.Penelitian ini menggunakan metode penelitian kualitatif deskriptif, dengan teknik pengumpulan data primer melalui observasi berdasarkan komentar-komentar pengguna Instagram pada unggahan foto Sarah Viloid, sedangkan data sekunder menggunakan studi pustaka (library research), jurnal, dan sumber internet. Analisa data yang digunakan dengan model Miles dan Huberman dan triangulasi untuk teknik keabsahan data. Luaran penelitian ini akan dipublikasi pada jurnal Fakultas Komunikasi dan Desain UNIBI.
\end{abstract}

Kata Kunci : Media Sosial; Instagram; Sarah Viloid; Pornoteks; Komentar Pornoteks di Instagram

\begin{abstract}
Social media, especially Instagram, has become one of the means to explore and express themselves. Instagram presents interactive features in facilitating its users, but not all Instagram users are wise and obey ethics in communicating on social media. This happened to Sarah Viloid's Selebgram account, which has millions of followers, after rising followers of Sarah, pornographic comments began to appear and are increasingly being found in almost every photo post of Sarah. Surely these comments will create discomfort, both for Sarah as the account owner, and for other Instagram users who read these obscene comments. This study uses descriptive qualitative research methods, with primary data collection techniques through observation based on Instagram user comments on Sarah Viloid photo uploads, while secondary data uses library research, journals, and internet sources. Data analysis used by the Miles and Huberman models and triangulation for data validity techniques. This research output will be published in the journal of the Faculty of Communication and Design UNIBI.
\end{abstract}

Keywords: Social Media; Instagram; Sarah Viloid; Pornotext; Pornotext Comments on Instagram 


\section{PENDAHULUAN}

\subsection{Latar Belakang}

Sejak kemunculannya pada tahun 2012, Instagram telah menarik banyak perhatian pengguna dan menimbulkan loyalitas dan intensitas para pengguna dalam menggunakan aplikasi interaktif ini. Fitur-fitur menarik yang disajikan seperti unggah foto, like, komentar, dan lain-lain menjadi aspek penunjang untuk meningkatkan eksistensi dan popularitas Instagram. Beberapa public figure dari segala bidang turut meramaikan Instagram dan tentunya langsung memiliki banyak pengikut dan komentar dari para penggemarnya, tetapi terkadang tidak semua public figure yang popular di Instagram atau bisa disebut selebgram mendapatkan komentar dan tanggapan yang positif dari pengguna Instagram lainnya, adapun yang mendapatkan tanggapan negatif berupa komentar yang mengandung unsur porteks dan pelecehan seksual.

Salah satu akun yang seringkali mendapatkan komentar berbau pornoteks adalah akun@sarahvilo.id, seorang gadis berusia 19 tahun yang pada awalnya merintis karir sebagai Youtuber Gaming. Eksistensinya di Instagram tidak kalah popular dengan di Youtube, berdasarkan observasi terbaru, akun@sarahvilo.id kini memiliki pengikut sejumlah 3.3 Juta dan masuk kategori akun bercentang biru atau verified account. Sarah cukup aktif dalam menggunakan Instagram, hampir setiap hari Sarah mengunggah foto pribadi di laman akun Instagram miliknya, dan terhitung sudah ada total 1.030 unggahan dari tahun 2016. Kolom komentar Sarah juga selalu ramai oleh pengguna Instagram lain, unggahan terakhirnya pada Senin, 6 April 2020 meraih 104.350 like dan lebih dari 600 komentar.

Berhubung Sarah merupakan seorang Youtuber Gaming perempuan, maka mayoritas penggemarnya adalah laki-laki yang juga berkecimpung di dunia games. Namun ternyata dengan banyaknya penggemar dan pengikut Sarah yang dominan laki-laki, komentar-komentar tidak senonoh dan berbau pornoteks sangat sering ditemui di hampir setiap unggahan Sarah. Komentarkomentar berbau pornoteks tersebut merupakan salah satu pergeseran konsep pornografi.
Pornoteks adalah karya pencabulan (porno) yang ditulis sebagai naskah cerita atau berita dalam berbagai versi hubungan seksual, dalam berbagai bentuk narasi, konstruksi cerita testimonial, atau pengalaman pribadi secara detail dan vulgar (Burhan Bungin, 2006), hal tersebut erat kaitannya dengan berbagai komentar yang sangat vulgar dari pengguna Instagram tentang hasrat seksual mereka pada tubuh Sarah yang ada didalam foto unggahanya.

Berdasarkan fenomena tersebut, tujuan khusus dalam penelitian ini untuk untuk mengupas lebih jauh tentang bagaimana pelecehan seksual yang ada di media sosial Instagram bisa terjadi pada sosok Sarah Viloid yang mulanya memulai karir sebagai Youtuber Gaming, kemudian meneliti seperti apa bentuk komentar yang dilontarkan oleh pengguna media sosial Instagram pada Sarah Viloid.

Penelitian yang akan dilakukan ini memiliki tingkat kepentingan atau urgensi yang besar, terutama untuk menghasilkan bahan evaluasi bagi pengguna Instagram dalam meminimalisir komentar-komentar yang mengundung unsur pornoteks dan pelecehan seksual dari segala pihak guna kenyamanan dan keamanan bagi setiap pengguna Instagram dalam bersosial media.

\subsection{Identifikasi Masalah}

Dari latar belakang di atas, penulis mengangkat suatu identifikasi masalah, yaitu: Seperti apa fenomena pornoteks yang terjadi di kolom komentar akun instagran@sarahvilo.id sebagai masalah sosial yang ada pada media baru?

\subsection{Tujuan Penelitian}

Adapun tujuan penelitian ini adalah untuk mengetahui tentang bagaimana fenomena pornoteks yang terjadi pada kolom komentar akun instagran@sarahvilo.id sebagai masalah social yang ada pada media baru. 


\section{KAJIAN PUSTAKA}

\subsection{Media Sosial}

Saat ini media sosial bisa dikatakan telah menjadi kebutuhan bagi masyarakat, terutama untuk generasi milenial dan generasi $\mathrm{Z}$. Media sosial banyak membantu perkembangan masyarakat, terutama dalam hal berkomunikasi dan bersoialisasi dengan kerabat dan teman-teman baru di dunia maya yang terpisah oleh jarak. Media sosial juga bisa menjadi sarana aktualisasi diri untuk mengembangkan kemampuan seseorang dalam mengekpresikan diri, baik dalam mempublikasikan keterampilan, mengemukakan pendapat dan menuangkan ide-ide secara bebas dalam fitur yang telah tersedia.

Menurut Nasrullah (2015:8), Media sosial merupakan website yang ditunjukan untuk menjalin pertemanan dan sosialisasi di internet. Media sosial adalah media online yang mendukung interaksi sosial. Media sosial menggunakan teknologi berbasis web yang mengubah komunikasi menjadi dialog interaktif. Perkembangan media sosial berdampak pada komunikasi kita saat ini. Munculnya web 2.0 memungkinkan orang membangun hubungan sosial serta berbagi informasi.

Media sosial juga adalah media berbasis
internet yang memungkinkan pengguna
berkesempatan untuk berinteraksi dan mempresentasikan diri, baik secara seketika ataupun tertunda, dengan khalayak luas maupun tidak yang mendorong nilai dari konten dan persepsi interaksi dengan orang lain lain (Caleb T. Carr dan Rebecca A. Hayes, 2015).

\subsection{Instagram}

Aplikasi berbasis online Instagram berhasil mencapai popularitas yang baik dan dapat diterima oleh masyarakat Indonesia, khusunya remaja yang menjadi pengguna utama Instagram. Fitur yang menarik menjadi daya tarik utama yang menjadi alasan Instagram masih terus bertahan dan terus berinovasi mengikuti perkembangan zaman.

Instagram merupakan situs jejaring sosial media sebagai layanan berbasis web yang memungkinkan perorangan untuk membangun profil umum atau semi umum dalam satu sistem yang terbatas, menampilkan pengguna lainnya yang berkaitan dengan mereka, dan melihat-lihat dan mengamati daftar koneksi yang mereka miliki maupun daftar yang dibuat oleh pengguna lainnya dalam sistem tersebut (Boyd dan Ellison, 2008:11).

Selain itu menurut Atmoko Dwi (2012), Instagram adalah sebuah aplikasi dari smartphone yang khusus untuk media sosial yang merupakan salah satu dari media digital yang mempunyai fungsi hampir sama dengan twitter, namun perbedaannya terletak pada pengambilan foto dalam bentuk atau tempat untuk berbagi informasi terhadap penggunanya. Instagram juga dapat memberikan inspirasi bagi penggunanya dan dapat meningkatkan kreatifitas, karena Instagram mempunyai fitur yang dapat membuat foto menjadi lebih indah, lebih artistik dan menjadi bagus.

\subsection{Komentar Porteks di Instagram}

Fitur komentar yang tersedia di Instagram tak hanya menimbulkan dan memberikan tanggapan yang baik antar pengguna Instagram, namun pada akun Instagram @sarahvilo.id terdapat banyak komentar negatif yang merujuk pada pelecehan seksual dan pornoteks di hampir setiap unggahan pribadinya. Adapun 3 hal yang mendasari komentar berunsur porteks ini bisa terjadi, yaitu: Uploading-Objetification, atau ketika akun Instagram@sarahvilo.id mengunggah sebuah foto yang kemudian membuat pengguna Instagram lain menanggapi dan memberikan komentar serta mengobyektifikasi unggahan foto@sarahvilo.id sebagai pemuas hasrat seksual.

Penjelasan lebih jauh mengenai kedua komponen tersebut adalah sebagai berikut:

1. Mengunggah - merupakan kegiatan sebuah pengguna Instagram untuk mengirimkan dan menyebarluaskan sebuah kiriman berupa foto, video, file, musik, dan lain-lain ke publik untuk mendapatkan berbagai tanggapan dari pengguna lain. Dalam hal ini, akun Instagram @ sarahvilo.id mengunggah foto yang dengan atau tanpa sengaja memperlihatkan dan menonjolkan bagian-bagian tubuhnya yang dianggap sensitif dan kurang senonoh bagi sebagian kalangan, sehingga dari 
proses mengunggah tersebut beragam tanggapan muncul, termasuk tanggapan dan komentar berunsur pornoteks dan pelecehan seksual.

2. Obyektifikasi - merupakan hal yang dilakukan oleh sebagian pengguna Instagram yang ditunjukan di kolom komentar pada unggahan foto @ sarahvilo.id. Obyektifikasi disini dalam artian bahwa pengguna Instagram mengobyektifikasi@sarahvilo.id sebagai objek seksual mereka berdasarkan unggahan-unggahan pribadinya. Menurut Burhan Bungin (2006), pada dasarnya hal ini berawal dari wacana seks yang menyatakan bahwa masalah tubuh perempuan sebagai objek porno, sebenarnya telah lama menjadi polemik dihampir semua masyarakat disebabkan karena adanya dua kutup dalam menilai tubuh manusia (terutama perempuan) sebagai objek seks.

\section{METODE PENELITIAN}

Dalam penelitian ini, penulis menggunakan paradigma penelitian kualitatif, atau penelitian yang bersifat subjektif. Penelitian kualitatif dimaksudkan agar penulis dapat mendeskripsikan secara jelas dan terperinci, serta mendapatkan data yang mendalam dari kasus yang diteliti.

Penelitian ini menggunakan metodologi penelitian kualitatif untuk mendeskripsikan dan menganalisis fenomena, peristiwa, aktivitas sosial, sikap kepercayaan, persepsi, pemikiran secara individual maupun kelompok (Nana Syaodih Sukmadinata, 2011). Metode kualitatif juga sebagai prosedur penelitian yang menghasilkan data deskriptif berupa kata-kata tertulis atau lisan dari orang-orang dan perilaku yang diamati. Data yang dihasilkan berupa kata-kata, gambar, serta perilaku manusia.

Metode penelitian kualitatif ini sering disebut metode penelitian naturalistic karena penelitiannya dilakukan pada kondisi yang alamiah (natural setting), sehingga metode ini sering disebut sebagai metode naturalistic. Objek alamiah adalah objek yang apa adanya, tidak dimanipulasi oleh peneliti sehingga kondisi pada saat memasuki objek, setelah berada dalam objek dan setelah keluar dari objek relative tidak berubah.

Teknik pengumpulan data pada penelitian ini dilakukan dengan pengumpulan data primer dan sekunder. Penelitian data primer yang dilakukan peneliti adalah Observasi. Sutrisno Hadi (1986) mengemukakan bahwa observasi merupakan suatu proses yang kompleks, suatu proses yang tersusun dari berbagai proses biologis dan psikologis. Dua diantara yang terpenting adalah proses-proses pengamatan dan ingatan.

Dalam penelitian ini, peneliti melakukan observasi non partisipan atau disebut juga observasi pasif, dimana peneliti melakukan pengamatan dan observasi pada aktivitas melalui sosial media akun Instagram @sarahvilo.id, baik dalam intensitas unggahan perhari, jumlah like dan komentar yang menjadi fokus kasus yang diangkat mengenai adanya komentar berunsur pornoteks dan pelecehan seksual. Apabila dirincikan, penelitian observasi non partisipan dilakukan sebagai berikut:

1. Mengamati intensitas dan jenis unggahan foto@sarahvilo.id di akun Instagramnya setiap hari yang menjadi pemicu timbulnya komentar berunsur pornoteks dan pelecehan seksual secara vulgar.

2. Mengamati gejala-gejala pelecehan seksual berupa pornoteks di kolom komentar@sarahvilo.id yang berasal dari sebagian pengikut dan penggemarnya.

3. Mengamati seberapa banyak dan seberapa sering komentar berunsur pornoteks muncul diunggahan foto@sarahvilo.id

Sedangkan untuk pengumpulan data sekunder, peneliti menggunakan teknik studi pustaka dimana peneliti mempelajari berbagai buku referensi serta hasil penelitian sebelumnya yang sejenis yang berguna untuk mendapatkan landasan teori mengenai masalah yang akan diteliti (Sarwono, 2006). Selain bersumber dari buku, peneliti juga melakukan pencarian referensi dari jurnal dan sumber internet mengenai pornografi dan media sosial, khususnya Instagram yang kemudian dapat dikaji dan diolah kembali dalam penelitian ini. 
Selanjutnya, penelitian ini menggunakan teknik analisa data dengan model Miles dan Huberman. Menurut Miles dan Huberman (1992:68) analisis terdiri dari tiga alur kegiatan dan tahapan yang terjadi secara bersamaan, yaitu: pengumpulan data (data collection), reduksi data (data reduction), penyajian data (data display), dan penarikan kesimpulan/verifikasi (conclutions).

Penelitian yang dilakukan peneliti tentunya tidak terlepas dari teknik pengujian keabsahan data yang dipergunakan sebagai pengecekan kebenaran data penelitian yang telah dikumpulkan. Teknik yang dilakukan dengan triangulasi data, triangulasi sumber dan triangulasi waktu. Triangulasi data diartikan sebagai penegcekan data dari berbagai sumber dengan berbagai cara dan berbagai waktu. Triangulasi sumber dilakukan dengan cara mengecek data yang telah diperoleh melalui beberapa sumber. Triangulasi teknik dilakukan dengan cara mengecek data kepada sumber yang sama dengan teknik yang berbeda. Misalnya data diperoleh dengan wawancara, lalu dicek dengan observasi, dokumenasi, atau kuisioner. Triangulasi waktu dilakukan dengan cara melakukan pengecekan dengan wawancara, observasi, atau teknik lain dalam waktu atau situasi yang berbeda (Sugiyono, 270-274). Maka dari itu, dalam hal ini peneliti mencoba membandingkan dan mengecek ulang berbagai aspek seperti aktivitas dan unggahan@sarahvilo.id yang terpantau di Instagram, serta seperti apa komentar berunsur pornoteks yang biasa muncul pada kolom komentar didalam unggahan.

\section{HASIL PEMBAHASAN}

4.1 Analisis Karakteristik Komentar pada Unggahan Sarah Viloid

Pelecehan seksual yang diterima oleh Sarah Viloid yang berupa komentar-komentar vulgar tidak bermoral yang rata-rata berasal dari kutup pertamapada wacana seks didalam pembahasan mengenai pelecehan seksual dan pornomedia, dimana kelompok ini memuja-muja tubuh Sarah sebagai objek seks, serta mereka menganggap bahwa tubuh Sarah adalah objek seks yang merupakan sumber kesenangan, kebahagiaan, dan keintiman. Telah didapatkan riset dalam 3 bulan terakhir mengenai isi dari komentar pada unggahan Sarah Viloid di Instagram.

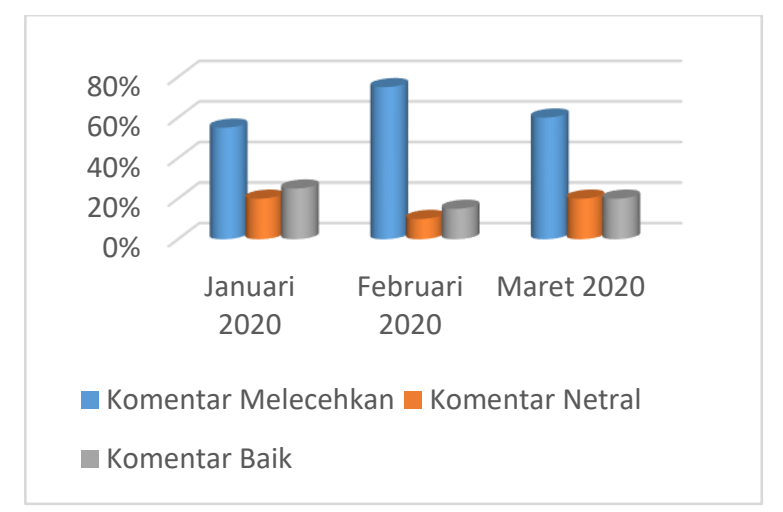

Pada grafik diatas, dapat terlihat bahwa isi komentar yang melecehkan selalu menempati posisi teratas dalam setiap foto-foto Sarah Viloid yang diambil dari bulan Januari 2020 sebesar 55\%, Februari sebesar 75\%, dan Maret sebesar 60\%. Bila ditinjau dari setiap unggahan, komentar melecehkan berasal dari akun dengan profil lakilaki, hal ini dikarenakan rata-rata penggemar Sarah adalah laki-laki, mengingat basic nya yang merupakan seorang gamers dari games yang memang disukai oleh mayoritas laki-laki.

Selain gamers, Sarah juga mempunyai penampilan yang cantik dan menarik sebagai daya tarik dan nilai plus dimata mereka, maka secara tidak langsung membuat mereka semakin tertarik untuk mengangumi Sarah dari segi apapun, dan tidak menutup kemungkinan, hal tersebut juga membuat mereka terpancing untuk mengimajinasikan Sarah sampai berani melontarkan komentar-komentar pelecehan seksual.

Dalam hal ini, Sarah Viloid tidak menggubris komentar-komentar yang melecehkan dirinya. Biasanya Sarah hanya membalas kommentar-komentar bebentuk pujian saja, seolaholah Sarah tidak peduli dan acuh terhadap banyaknya komentar kurang mengenakan yang melecehkan dirinya. Mungkin ini juga menjadi salah satu alasan mengapa pihak yang melecehkan tidak merasa bersalah atau kapok untuk berkomentar seperti itu, karena Sarah sendiri terlihat tidak keberatan. Hasil observasi yang didapat menegelompokan 3 karakteristik komentar 
yang ada didalam setiap foto-foto Sarah Viloid sebagai berikut:

\section{a) Komentar Baik}

Komentar yang termasuk kedalam kategori ini adalah berupa dukungan, pujian, dan hal-hal yang baik menyangkut Sarah Viloid. Umumnya komentar ini datang dari penggemar Sarah baik laki-laki maupun perempuan yang benar-benar mengidolakan Sarah berdasarkan keahliannya dalam bermain games. Mereka berkomentar tentang kesuksesan karirnya di bidang Content Creator, Entertainer game, dan gamers online professional. Diantara mereka juga sering memuji penampilan Sarah yang cantik dan menarik sebagai daya tarik sendiri.

\section{b) Komentar Netral}

Komentar yang termasuk kedalam kategori ini biasanya berupa ajakan bermain game bersama ataupun pemberian saran untuk konten yang dibuat Sarah di Youtube. Selain itu, bagi online shop atau akun bisnis yang biasa mempromosikan produknya, mereka akan memanfaatkan peluang pada akun Sarah sebagai sarana promosi dimana mereka ikut berkomentar pada unggahan yang berpotensi menarik banyak pengguna lain, tetapi komentar yang mereka tulis hanya untuk mempromosikan produknya. Melihat banyaknya orang yang mengunjungi profil Sarah untuk berkomentar maka hal tersebut memberikan kesempatan untuk akun online shop mendapat kunjungan juga dari pengikut Sarah.

\section{c) Komentar Melecehkan}

Kategori komentar ini berisi hal-hal vulgar yang menyangkut tentang tubuh Sarah, tidak hanya itu terkadang isi komentar juga menjadikan tubuh Sarah sebagai objek seks dan hal yang berbau porno untuk kesenangan pribadi. Mayoritas pengguna akun yang melontarkan komentar melecehkan adalah laki-laki. Dilihat dari cara mereka berkomentar, terlihat bahwa mereka sangat memperhatikan fisik dan penampilan Sarah. Saat Sarah menggunakan pakaian yang pendek atau terbuka, mereka cenderung berkomentar tentang bagaimana tubuh Sarah terekspos jelas, atau ketika Sarah menggunakan pakaian yang ketat, mereka berkomentar mengenai lekukan tubuh Sarah yang dianggap menarik, tentunya mereka tidak beranggapan bahwa itu adalah pelecehan seskual yang serius, melainkan mereka anggap sebagai hiburan

\subsection{Contoh Konkrit Komentar Pelecehan Seksual pada Unggahan Instagram Sarah Viloid.}

Dalam kasus ini, telah diambil masingmasing 1 foto dalam setiap bulan pada tahun 2020 sesuai dengan grafik yang telah dibuat. Pengambilan foto dilihat berdasarkan banyaknya komentar-komentar yang memuat pelecehan seksual dan potensi yang dianggap menimbulkan pelecehan tersebut pada Sarah Viloid. Berikut contoh dan rinciannya:

\section{a) Januari 2020}

Foto yang diunggah pada 14 Januari 2020 ini mendapatkan 20.000 lebih komentar. Pada foto Sarah tampil dengan mengenakan kaos berwarna abu-abu. Tidak disangka, pakaian dan pose Sarah berpotensi munculnya komentar berbau pelecehan seksual sebagaimana ditandai pada gambar 4 .

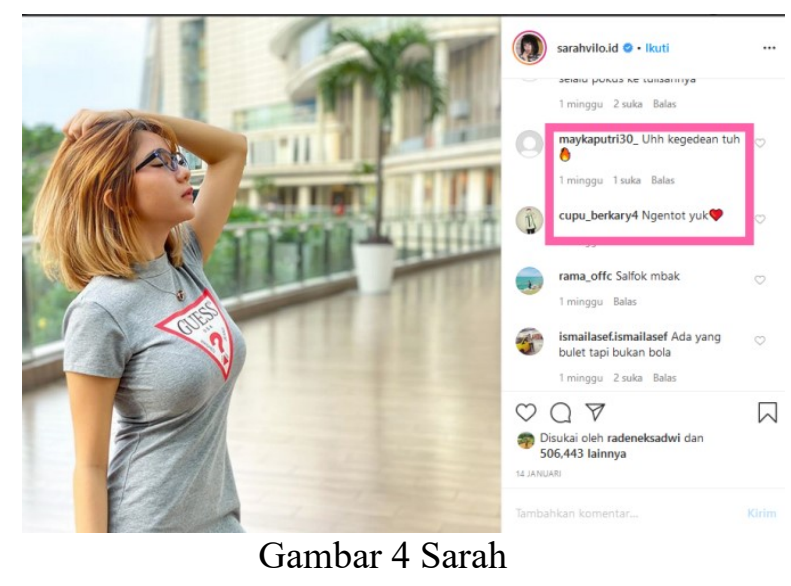

Kedua pengguna Instagram tersebut menuangkan komentar bernada seksual dengan cara yang berebeda, komentar@maykaputri30 lebih kepada bagian tubuh Sarah yang dianggap terlalu besar, jika dilihat sekilas maka dapat ditangkap maksud dari akun tersebut menjurus kepada bagian dada Sarah. Berbeda hal nya dengan 
akun@cupu berkarya4 yang secara gamblang mengajak Sarah untuk berhubungan intim dengan menggunakan kata yang cukup kasar dan tidak sopan. Sebagian dari laki-laki memang menyukai seseuatu yang berbau pornografi. Bagi laki-laki hal itu cocok bagi desakan biologis mereka karena hal yang berbaru pornografi memperlihatkan dengan jelas gambar-gambar dan bentuk-bentuk, birahi dan seks.

\section{b) Februari 2020}

Unggahan foto pada 26 Februari 2020 ini mendapatkan 4.000 komentar, sayangnya sangat banyak didapati komentar bernada seksual seperti yang tertangkap pada gambar diatas, pelecehan seskual nampak tertulis secara jelas dan vulgar. Dalam foto ini terlihat Sarah mengenakan pakaian yang sama dengan unggahan pada 14 Janurari 2020, dengan menggunakan tas selempang sebagai aksesoris tambahan.

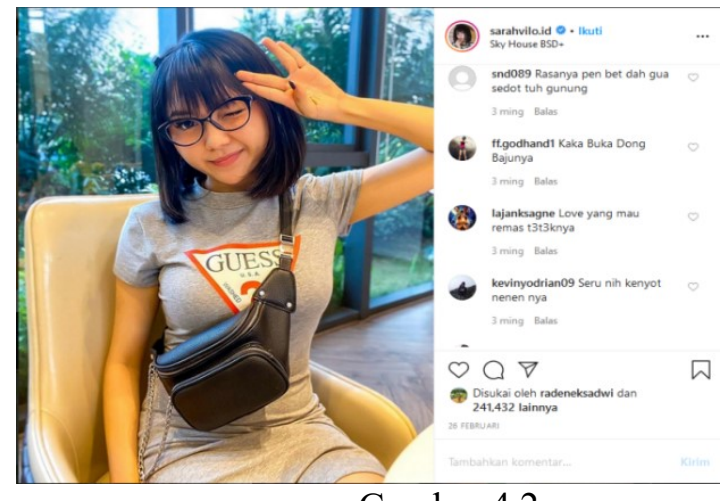

Gambar 4.2

Namun pada unggahan ini ternyata lebih memancing komentar bernada seksual dibandingkan unggahan sebelumnya. Akun @ kevinyodrian09 berkomentar tentang keinginan dan imajinasinya mengenai payudara Sarah, begitupun dengan akun @lajanksagne dan @and089. Kemudian akun@ff.godhand1 tak raguragu untuk meminta Sarah membuka bajunya.

Dari kedua unggahan dengan baju yang serupa dapat terlihat bahwa pakaian ketat yang Sarah gunakan menambah peluang dan potensi komentar pelecehan seksual atau pornoteks bermunculan. Hal ini tidak mengherankan karena pada dasarnya laki-laki berkomentar seperti itu dikarenakan mereka terangsang melalui mata mereka. Otak laki-laki tersusun untuk melihat pada bentuk tubuh wanita, dan karena itulah gambar-gambar yang erotis sangatlah berpengaruh bagi mereka.

\section{c) Maret 2020}

Unggahan video boomerang pada 8 Maret 2020 ini mendapatkan 1.000 lebih komentar. Sama halnya dengan 2 unggahan pada bulan sebelumnya, kali ini komentar bernada seksual atau pornoteks tetap seringkali ditemukan. Kali ini Sarah mengenakan kaos bermotif dan rok jeans pendek, lagi-lagi hal ini menjadi peluang dan potensi timbulnya komentar berunsur pelecehan seksual kepadanya seperti pada gambar 4.3.

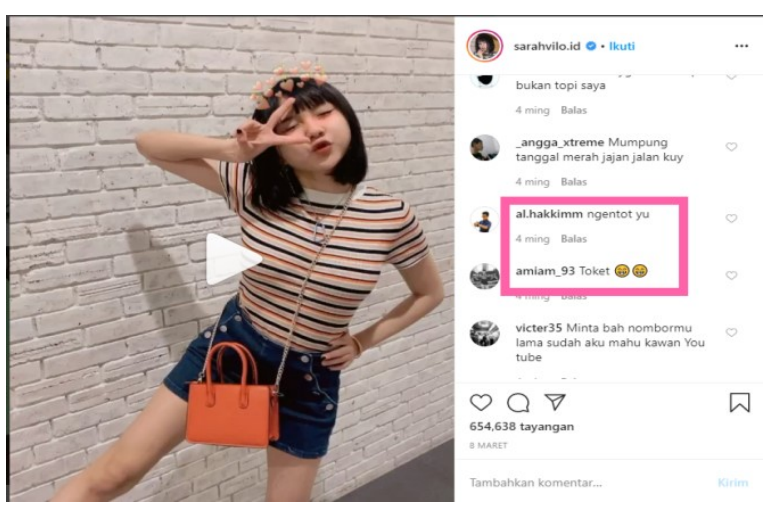

Gambar 4.3

Akun@al.hakkim berkomentar mengenai keinginanya berhubungan intim dengan Sarah, pemilihan kata yang ia gunakan tentu sangat tidak beretika. Meskipun kali ini Sarah tidak mengenakan baju seketat salah satu unggahan pada 2 bulan sebelumnya, namun kini bagian paha Sarah terekpos dan hal itu menjadi daya tarik baru bagi sebagian akun yang seringkali berfikir tentang seksual pada Sarah.

Dikutip dari buku Why Men Don't Listen and Women Can't Read Maps, 2014 dinyatakan bahwa Laki-laki tertarik pada lekuk pinggang, panjang tungkai, dan bentuk tubuh. Wanita manapun dengan bentuk tubuh dan perbandingan yang tepat, akan menarik perhatiannya. Hal ini selaras dengan 
unggahan Sarah yang mengampilkan lekukan tubuhnya sampai batas lutut dan kemudian menimbulkan rangsangan mengenai kriteria pembangkit gairah visual dan jasmani yang membuat mereka berfantasi tentang seksualitas yang ada pada Sarah Viloid.

\section{KESIMPULAN}

Maka dapat disimpulkan bahwa Pelecehan seksual termasuk kedalam masalah sosial dan media baru. Dimana, saat pengguna Instagram menulis sebuah komentar pada unggahan pengguna lainya, maka komentar tersebut telah tersebar dan menjadi konsumsi seluruh pengguna Instagram yang membacanya. Hal ini terjadi pada akun selebgram Sarah Viloid yang kerap kali mendapatkan komentar tidak senonoh berupa ujaran-ujaran pornoteks di setiap foto yang diunggahnya.

Media sosial khusunya Instagram memang menyajikan fitur-fitur yang interaktif guna memudahkan penggunanya dalam bekomunikasi dan berosialisasi di dunia maya karena terkendala waktu maupun jarak. Fitur-fitur yang disediakan juga bisa dinikmati oleh siapapun secara gratis dan tidak terbatas, maka hal tersebut memungkinkan komentar berunsur pornoteks tak jarang ditemui, ini dikarenakan tidak adanya aturan khusus atau hukuman yang menjerat pada akun dengan komentar seperti itu, terkecuali jika pemilik akun yang yang dikomentari seperti hal nya Sarah Viloid merasa keberatan dan melaporkan tindakan tersebut.

Adapun penyebab munculnya komentar berunsur pornoteks tersebut dikarenakan unggahan foto Sarah Viloid dianggap menjadi stimulus atau rangsangan bagi sebagian pengguna Instagram yang melihat, kemudian timbul berbagai sudut pandang, kebanyakan sudut pandang menangkap bahwa foto Sarah Viloid itu vulgar dan nampak seronok dengan pakaian minim atau ketat sehingga terjadilah feedback dari mereka terhadap foto tersebut yang dituangkan lewat kolom komentar.

Hal ini pun berkaitan dan berawal dari wacana seks sebagai bagian dari pelecehan seksual dan pornomedia. Sebagaimana dijelaskan bahwa masalah tubuh perempuan sebagai objek porno, sebenarnya telah lama menjadi polemik dihampir semua masyarakat disebabkan karena adanya dua kutup dalam menilai tubuh manusia (terutama perempuan) sebagai objek seks. Pertama: kelompok yang memuja tubuh perempuan sebagai objek seks serta merupakan sumber kebahagiaan, kesenangan, keintiman, status sosial, dan seni. Kedua: kelompok yang menuduh seks sebagai objek maupun sebjek dari sumber malapetaka bagi kaum perempuan itu sendiri.

Pada kasus ini. Kutup pertama menjadi kelompok yang sesuai dengan isi komentar berunsur pornoteks pada unggahan Sarah Viloid. Hal ini dikarenakan pengguna Instagram tersebut merasa foto yang menunjukan tubuh Sarah adalah sebagai sumber kesenangan dan hiburan bagi mereka. Maka dari itu, mereka cenderung merasa senang dan mengutarakan hasrat seksualnya pada Sarah tanpa merasa canggung. Oleh karena itu diperlukan literasi media da penaatan terhadap etika dalam berkomunikasi di Sosial media guna memberikan kenyamanan bagi setiap pengguna.

\section{REFERENSI}

Bungin, Burhan.2006.Sosiologi

Komunikasi.Jakarta: Kencana

Nasrullah, Rulli.(2015). Media Sosial Perspektif Komunikasi, Budaya dan Sosioteknologi. Bandung: Simbiosa Rekatama Media

Carr, Caleb T., \& Hayes, Rebecca A. 2015. Social Media: Definin, Developing, and Diviningl, Atlantic Journal of Communication.

Ellison \& Boyd. 2008. Journal Computer Mediated Communication. Amertika: Tarleton State University

Atmoko Dwi, Bambang. 2012. Instagram Handbook Tips Fotografi Ponsel. Jakarta: Media Kita.

Sugeng, Anang.(2016). Pengaruh Media sosial terhadap perubahan sosial masyarakat di Indonesia. Tulungagung: jurnal.unita.org 
Fathu, Ulfah.(2016). Gambaran keterpaparan media massa berkonten pornografi pada usia mencarche di wilayah kecamatan Pancoran mas-Depok.Jakarta: repository.uinjkt.ac.id

Intan, Putri.(2018). Peran media dengan konten pornografi terhadap perilaku seksual remaja.Surakarta: eprints.ums.ac.id

Ayu, Andrea.(2018). Analisis kriminologis terjadinya kejahatan pornografi terhadap anak melalaui media elektronik.Lampung: jurnal.fh.unila.ac.id

Nana Syaodih Sukmadinata. (2011). Metode Penelitian Pendidikan. Bandung: PT Remaja Rosdakarya.

Hadi, Sutrisno. 1986. Metodologi Research. Yogyakarta: Andi Offset.

Jonathan, Sarwono. 2006.Metode Penelitian Kuantitatif dan Kualitatif.Yogyakarta:Graha Ilmu
Miles, B. Mathew dan Michael Huberman. 1992. Analisis Data Kualitatif Buku Sumber Tentang Metode-metode Baru.Jakarta: UIP.

Sugiyono. 2005. Memahami Penelitian Kualitatif. Bandung: CV. Alfabeta.

Pease, Barbara, and Allan.2014.Why Men Don't Listen and Women Can't Read Maps.Jakarta: Cahaya Insan Suci 